\title{
Growth, accumulation and uptake of Eichhornia crassipes exposed to high cadmium concentrations
}

\author{
Eliana Melignani ${ }^{1,2}$ (D) Ana María Faggi ${ }^{3} \cdot$ Laura Isabel de Cabo $^{2}$ \\ Received: 26 November 2018 / Accepted: 14 May 2019 \\ (C) Springer-Verlag GmbH Germany, part of Springer Nature 2019
}

\begin{abstract}
A greenhouse experiment was performed to evaluate the growth, accumulation, and uptake rate of Eichhornia crassipes subject to high cadmium concentrations. Three doses of Cd were added to polluted river water $(1,5$, and $10 \mathrm{mg} \mathrm{Cd} / \mathrm{L})$, and polluted water with basal $\mathrm{Cd}$ concentration $(0.070 \mathrm{mg} / \mathrm{L})$ was used as a control. The experiment lasted for 7 days. Signs of stress and toxicity were visible in all treatments from day 3 of the experiment. The growth of the water hyacinth was slightly stimulated in the presence of low Cd concentration $(1 \mathrm{mg} / \mathrm{L}$ ), but this could also be due to the chloride and other nutrients present in the polluted water. $\mathrm{Cd}$ was accumulated mainly in roots, showing a maximum concentration of $1742.1 \mathrm{mg} \mathrm{Cd} / \mathrm{kg} \mathrm{dw}(10 \mathrm{mg} \mathrm{Cd} / \mathrm{L})$. The translocation from roots to leaves was low, with a maximum accumulation of $147.4 \mathrm{mg} \mathrm{Cd} / \mathrm{kg} \mathrm{dw}(10 \mathrm{mg} \mathrm{Cd} / \mathrm{L})$. The uptake rate for roots reached a maximum of $248.7 \mathrm{mg} \mathrm{Cd} / \mathrm{kg}$.day while the uptake rate for leaves did not saturate in the range of the studied concentrations (max. $20.8 \mathrm{mg} \mathrm{Cd} / \mathrm{kg} \cdot d a y$ ). The water hyacinth showed promising results for the application in the treatment of Cd-polluted waters given its ability to tolerate high Cd concentrations in the media (up to $10 \mathrm{mg} \mathrm{Cd} / \mathrm{L}$ ) and its capacity for uptake and accumulation.
\end{abstract}

Keywords Aquatic plants $\cdot$ Trace elements $\cdot$ Water hyacinth

\section{Introduction}

Environmental pollution caused by trace elements has become a serious issue worldwide. In nature, the mobilization of metals, such as $\mathrm{Pb}, \mathrm{Cd}, \mathrm{Ni}, \mathrm{Co}, \mathrm{Cr}, \mathrm{Cu}$, or $\mathrm{Ag}$, in the biogeochemical cycles is minimum. These elements are mainly

Responsible editor: Elena Maestri

Eliana Melignani

elianameli@bg.fcen.uba.ar

1 Present address: Instituto de Micología y Botánica - Consejo Nacional de Investigaciones Científicas y Técnicas, Departamento de Biodiversidad y Biología Experimental, Facultad de Ciencias Exactas y Naturales, Universidad de Buenos Aires, Av. Int. Güiraldes 2160, Ciudad Universitaria, C1428EGA Ciudad Autónoma de Buenos Aires, Argentina

2 Museo Argentino de Ciencias Naturales "Bernardino Rivadavia" Consejo Nacional de Investigaciones Científicas y Técnicas, Av. Ángel Gallardo 470, C1405DJR Ciudad Autónoma de Buenos Aires, Argentina

3 Facultad de Ingeniería, Universidad de Flores, Pedernera 275, C1406EEF Ciudad Autónoma de Buenos Aires, Argentina found in reservoirs, but mining extraction and its subsequent processing for different applications release them to the environment (Ali et al. 2013). Urbanization, industrialization, and transportation, among other human activities, favor the dispersion of trace elements in the water and the atmosphere (Nagajyoti et al. 2010).

Cadmium (Cd) is considered a non-essential element that negatively affects all types of organisms. It is highly soluble in water and it has been classified as an element of intermediate toxicity (Sanità di Toppi and Gabbrielli 1999; Benavides et al. 2005). It is frequently used in the industry of electroplating, pigments, plastic stabilizers, and batteries, and it is a by-product of phosphate fertilizers (Lux et al. 2011; Gallego et al. 2012; Tran and Popova 2013). Cadmium alters plant growth and development by interference in the uptake, transport, and use of various elements $(\mathrm{Ca}, \mathrm{Mg}, \mathrm{P}$, and $\mathrm{K}$ ) (Benavides et al. 2005). It reduces the absorption of nitrates and its transport from root to shoot, affecting the water balance in the plant, and it also has negative effects on membrane phospholipids and photosynthesis metabolism (Sanità di Toppi and Gabbrielli 1999; Benavides et al. 2005; RodríguezSerrano et al. 2008; Tran and Popova 2013). 
Among the most industrialized and crowded areas in the world, there is a river located in Argentina that is considered one of the ten most polluted sites in the world (ECYT-AR 2011; Bernhardt and Gysi 2013). In the metropolitan area of Buenos Aires, the Matanza-Riachuelo river (MR river), a typical plain river, is subject to strong anthropogenic disturbances (Gómez 1998), in particular the lower part of the basin, called "Riachuelo." Trace elements are among the most conspicuous contaminants in water, soil, and sediments in the basin, and phytoremediation has been proposed as a likely strategy to decrease this burden (Basílico et al. 2016).

Phytoremediation involves the use of plants to reduce the concentration or toxic effect of different kind of pollutants (trace elements, organic compounds, and other xenobiotics) in the environment. Plants can modify contaminants in a variety of processes (removal, reduction, transformation, mineralization, degradation, etc.). This technology poses many benefits since it is efficient, cost-effective, and environmentally friendly (Ali et al. 2013). Among the plants that have been tested for phytoremediation purposes, many floating macrophytes have shown great capacity of tolerance and absorption of heavy metals. Salvinia (Phetsombat et al. 2006; Dhir and Srivastava 2011), Lemna (Khellaf and Zerdaoui 2010), Pistia (Sukumaran 2013), Eichhornia (Rezania et al. 2015), and Azolla (Sood et al. 2012) are among the most studied genera (Ali et al. 2013; Dixit et al. 2015; Rezania et al. 2016). Various species of floating macrophytes have been able to tolerate and absorb high Cd concentrations (> $1000 \mathrm{mg} \mathrm{Cd} / \mathrm{kg}$ ). Some examples are Limnocharis flava (Abhilash et al. 2009) and Salvinia cucullata (Phetsombat et al. 2006). In particular, the water hyacinth Eichhornia crassipes (Mart.) Solms has been extensively studied for its application in phytoremediation and has shown an interesting capacity for the accumulation and biosorption of heavy metals (Rezania et al. 2015). Metals, such as mercury, induce responses of oxidative stress and DNA damage in E. crassipes (Malar et al. 2015). Also, the water hyacinth has efficient molecular mechanisms (antioxidative enzymes) to tolerate lead accumulation in their tissues, indicating that it is a feasible plant for phytoremediation of polluted water containing lead (Malar et al. 2014).

There are several studies on the effect of cadmium on water hyacinth, but few of them explore the addition of this metal in high concentrations in polluted waters (e.g., Soltan and Rashed 2003; Hasan et al. 2007). We have previously evaluated the accumulation and tolerance of this species to copper, an essential element, under stressful conditions (Melignani et al. 2015). Since we obtained promising results, we were also interested in testing similar conditions for a nonessential element, cadmium. Both the cadmium and the water hyacinth are present in polluted water bodies with industrial and domestic effluent discharge. The tolerance described for this species under this stressful circumstance, could be applied in the treatment of industrial effluents. Therefore, the objective of this study was to evaluate the growth of water hyacinth exposed to high $\mathrm{Cd}$ concentrations added to polluted river water (Riachuelo water), as well as its accumulation and uptake rate in a short-term exposure experiment.

\section{Materials and methods}

\section{Plant and water collection}

Plant material (water hyacinth, E. crassipes) and the surficial water for the experiment were sampled from the Riachuelo section of the MR river ( $\left.34^{\circ} 38^{\prime} 12^{\prime \prime} \mathrm{S}, 58^{\circ} 21^{\prime} 05^{\prime \prime} \mathrm{W}\right)$, Buenos Aires, Argentina, on February 2012. The plants were cleaned with tap water and acclimatized in a hydroponic system (diluted Hoagland solution in a greenhouse with natural photoperiod) for 2 months. After propagation, individuals of the second generation were selected for the experiment (April 2012).

\section{Experimental set-up}

Cadmium (as $\mathrm{CdCl}_{2} \cdot 2 \frac{1}{2} \mathrm{H}_{2} \mathrm{O}$, analytical-grade reagent) was added to the river water in three concentrations: 1,5 , and $10 \mathrm{mg} / \mathrm{L}$ (treatments $\mathrm{Cd} 1, \mathrm{Cd} 5$, and Cd10, respectively). The river water without $\mathrm{Cd}$ supplement (basal concentration: $0.07 \mathrm{mg} / \mathrm{L})$ was used as a control $(\mathrm{Cd} 0)$. One or two individuals of water hyacinth (200 $\mathrm{g}$ fresh weight) were placed in plastic reactors with $4 \mathrm{~L}$ of the water (3 replicates per treatment and control). The plants were exposed to the metal for 7 days under greenhouse conditions (natural photoperiod, controlled temperature $22.0 \pm 1.9{ }^{\circ} \mathrm{C}$, and $\mathrm{pH} 7.55 \pm 0.24$ ). The water volume of the reactors was kept constant by adding deionized water.

\section{Sampling and analysis}

At the beginning of the experiment, three individuals of water hyacinth were separated from the hydroponic system and three water samples were taken from each treatment in order to measure initial $\mathrm{Cd}$ concentrations (in plant tissue and water) and initial dry biomass of E. crassipes. At the end of the experiment, plants and water samples were collected from each reactor. Plants were washed, separated into roots and leaves, and oven-dried at $70{ }^{\circ} \mathrm{C}$ for $72 \mathrm{~h}$. Then, they were digested with a mixture of concentrated nitric, perchloric, and clorhydric acids (10:2:5) (Soltan and Rashed 2003; Mishra and Tripathi 2008; Melignani et al. 2015). In water samples, $\mathrm{Cd}$ was measured without digestion. The metal was determined by flame atomic absorption spectrophotometry (flame-AAS) (detection limit for $\mathrm{Cd} 0.028 \mathrm{mg} / \mathrm{L}$ ). Water physicochemical parameters were determined as described by APHA (1999). The $\mathrm{NH}_{4}{ }^{+}$concentration was measured in 
water samples and the $\mathrm{N}-\mathrm{NH}_{3}$ concentration was estimated from this measure $\left(\mathrm{NH}_{4}{ }^{+}\right)$according to Körner et al. (2001).

Initial concentrations of $\mathrm{Cd}$ in water were $100 \pm 10 \%$ of nominal concentrations. The initial dry weight of E. crassipes plants was $1.38 \pm 0.12 \mathrm{~g}$ (mean \pm standard error) for roots and $1.74 \pm 0.13 \mathrm{~g}$ for leaves. Initial $\mathrm{Cd}$ content in roots was $1.32 \pm 0.03 \mathrm{mg} / \mathrm{kg}$ and $1.71 \pm 0.16 \mathrm{mg} / \mathrm{kg}$ in leaves. These concentrations of $\mathrm{Cd}$ in tissue were below the toxic limit for this metal (5-10 mg/kg) (White and Brown 2010).

\section{Growth estimation, cadmium translocation and uptake rate}

The parameters for growth estimation and metal translocation in tissue were calculated as described earlier (Melignani et al. 2015). The relative growth rate ( $\mathrm{RGR}$ day $^{-1}$ ) was calculated as: $\mathrm{RGR}=(\ln D W f-\ln D W i) / t$, where $D W f=$ dry weight at the end of the experiment $(\mathrm{g}) ; D W i=$ initial dry weight $(\mathrm{g})$; and $t=$ duration of the experiment (days). The growth stimulation percentage (GS, \%) (modified from the growth inhibition percentage equation; Park et al. 2011) was estimated as $\mathrm{GS}=(R G R t / R G R c-1) \times 100$, where $R G R t=$ relative growth rate for treatment $x$ and $R G R c=$ relative growth rate for respective control. The bioconcentration factor (BCF) was calculated as $\mathrm{BCF}=\mathrm{Cr} / \mathrm{Cw}$, where $\mathrm{Cr}=\mathrm{Cd}$ concentration in roots $(\mathrm{mg} / \mathrm{kg} \mathrm{dw})$ and $C w=\mathrm{Cd}$ concentration in water $(\mathrm{mg} / \mathrm{kg})$. The translocation factor $(\mathrm{TF})$ was estimated as $\mathrm{TF}=\mathrm{Cl} / \mathrm{Cr}$, where $\mathrm{Cl}=\mathrm{Cd}$ concentration in leaves $(\mathrm{mg} / \mathrm{kg}$ dw).

The capacity of E. crassipes for Cd uptake was estimated as the metal uptake rate for roots or leaves (UR, $\mathrm{mg} / \mathrm{kg}$ day) according to Singh and Agrawal (2007): UR $=(\mathrm{Cf}-\mathrm{Ci}) / t$, where $C f=$ final $\mathrm{Cd}$ concentration in biomass (roots or leaves) $(\mathrm{mg} / \mathrm{kg} \mathrm{dw})$ and $\mathrm{Ci}=$ initial $\mathrm{Cd}$ concentration in biomass (roots or leaves) $(\mathrm{mg} / \mathrm{kg} \mathrm{dw})$. A functional relation was investigated between the uptake rate and the $\mathrm{Cd}$ concentration in water and a linear regression analysis was performed. Data were tested for normal distribution (Shapiro-Wilks' test) and for homogeneity of variance (Levene's test). Metal concentrations were scaled when the relation between both variables was not linear. The test was compared at a level of $p<0.05$.

\section{Statistical analysis}

Data were statistically analyzed with the ANOVA test. Normality and homogeneity of variance were checked with Shapiro-Wilks' test and Levene's test, respectively. When the assumptions were not satisfied, a natural-log transformation of the data was applied. Tukey's test was performed to differentiate between treatments. The significance level of comparison for all tests was $p<0.05$.

\section{Results}

The physicochemical characteristics of the river water used in the experiment are shown in Table 1. The level of ammonium and trace elements $(\mathrm{Cu}, \mathrm{Cd}, \mathrm{Cr}, \mathrm{Ni}$, and $\mathrm{Pb})$ exceed the national water quality guidelines for the protection of aquatic life (National Law No. 24051 on Hazardous Waste) (Argentina 1991). Also, the level of $\mathrm{Cd}$ exceeds the international water quality guidelines for the protection of aquatic life $(\mu \mathrm{g} \mathrm{Cd} / \mathrm{L}$ : 0.15-0.40, DWAFF 1996; 0.06-0.80, ANZECC and ARMCANZ 2000; 0.09-1.0, CCME 2014; 0.25-2.0, USEPA 2016). Thus, the water used for this experiment is considered as polluted.

From the third day of the experiment, leaves and petioles in all treatments showed loss of turgor. Leaves showed invaginations in their lamina. Chlorosis and dry leaves were also evident from the third day, but only in treatment $\mathrm{Cd} 10$.

Table 1 Initial physicochemical characteristics of Riachuelo water and reference value (designated use: protection of aquatic life, as stated in the Argentinian National Law No. 24051 on Hazardous Waste)

\begin{tabular}{|c|c|c|}
\hline Parameter & $\begin{array}{l}\text { Value }^{1} \\
(\mathrm{mg} / \mathrm{L})\end{array}$ & $\begin{array}{l}\text { Reference value }{ }^{2} \\
(\mathrm{mg} / \mathrm{L})\end{array}$ \\
\hline \multicolumn{3}{|l|}{ Macronutrients } \\
\hline $\mathrm{Ca}$ & 55.95 & - \\
\hline $\mathrm{K}$ & 13.33 & - \\
\hline $\mathrm{Mg}$ & 26.78 & - \\
\hline $\mathrm{N}-\mathrm{NH}_{4}{ }^{+}$ & 14.03 & 1.37 \\
\hline $\mathrm{NO}_{2}^{-}$ & 0.014 & 0.06 \\
\hline $\mathrm{NO}_{3}^{-}$ & 0.18 & - \\
\hline SRP (as orthophosphate) & 1.70 & - \\
\hline $\mathrm{SO}_{4}^{-2}$ & 72.30 & - \\
\hline \multicolumn{3}{|l|}{ Micronutrients } \\
\hline $\mathrm{Cl}$ & 255.85 & - \\
\hline $\mathrm{Cu}$ & 0.033 & 0.002 \\
\hline $\mathrm{Fe}$ & 0.62 & - \\
\hline $\mathrm{Na}$ & 150.00 & - \\
\hline $\mathrm{Zn}$ & 0.073 & - \\
\hline \multicolumn{3}{|l|}{ Non-essential heavy metals } \\
\hline $\mathrm{Cd}$ & 0.070 & 0.0002 \\
\hline $\mathrm{Cr}$ & 0.073 & 0.002 \\
\hline $\mathrm{Ni}$ & 0.17 & 0.025 \\
\hline $\mathrm{Pb}$ & 0.073 & 0.001 \\
\hline \multicolumn{3}{|l|}{ Other physicochemical parameters } \\
\hline Alkalinity $\left(\right.$ as $\mathrm{CO}_{3}{ }^{-2}$ ) & 543.76 & - \\
\hline TOC (total organic carbon) & 15.22 & - \\
\hline DOC (dissolved organic carbon) & 9.52 & - \\
\hline $\mathrm{pH}$ & 7.14 & - \\
\hline
\end{tabular}

\footnotetext{
${ }^{1}$ Mean of three replicates

${ }^{2}$ Argentinian National Law No. 24051 on Hazardous Waste, Regulatory Decree No. 831/93, Annex II, Table 2
} 
Table 2 Dry weight of E. crassipes roots and leaves, relative growth rate (RGR) and growth stimulation percentage (GS) of plants after 7 days of $\mathrm{Cd}$ exposure

\begin{tabular}{lllll}
\hline Treatments & Roots $(\mathrm{g})$ & Leaves $(\mathrm{g})$ & RGR $\left(\right.$ day $\left.^{-1}\right)$ & GS $(\%)$ \\
\hline Cd0 (control) & $3.34 \pm 1.09 \mathrm{a}$ & $3.50 \pm 0.99 \mathrm{a}$ & $0.100 \pm 0.009 \mathrm{a}$ & - \\
$\mathrm{Cd} 1$ & $3.70 \pm 0.63 \mathrm{a}$ & $4.07 \pm 0.96 \mathrm{a}$ & $0.121 \pm 0.007 \mathrm{~b}$ & $22 \pm 4 \mathrm{a}$ \\
$\mathrm{Cd} 5$ & $1.72 \pm 0.36 \mathrm{~b}$ & $3.54 \pm 0.33 \mathrm{a}$ & $0.102 \pm 0.019 \mathrm{ab}$ & $3 \pm 12 \mathrm{~b}$ \\
$\mathrm{Cd} 10$ & $1.42 \pm 0.67 \mathrm{~b}$ & $3.52 \pm 0.33 \mathrm{a}$ & $0.102 \pm 0.018 \mathrm{ab}$ & $2 \pm 12 \mathrm{~b}$ \\
\hline
\end{tabular}

Values expressed as mean $(n=3) \pm$ std. error. Different letters under the same column indicate significant differences $(p<0.05)$ among treatments

$C d 0$ control (no metal addition), $C d 1$ supplemented with $1 \mathrm{mg} \mathrm{Cd} / \mathrm{L}, C d 5$ supplemented with $5 \mathrm{mg} \mathrm{Cd} / \mathrm{L}, C d 10$ supplemented with $10 \mathrm{mg} \mathrm{Cd} / \mathrm{L}$

\section{Growth estimation}

Final dry weight of root and leaf biomass, relative growth rates (RGR) and growth stimulation percentage (GS) are shown in Table 2. Root biomass was reduced by half in treatments $\mathrm{Cd} 5$ and $\operatorname{Cd} 10(F=20.65, d f=3, p=0.0004)$. In contrast, leaf biomass did not show significant differences from the control in any treatment $(F=1.20, d f=3, p=0.3685)$. The RGR showed a slight increase in treatment $\operatorname{Cd} 1(F=4.44, d f=3, p=$ $0.0407)$, consistent with growth stimulation $(22 \%)(F=$ $10.34, d f=2, p<0.0114)$.

\section{Cadmium accumulation}

Table 3 shows the $\mathrm{Cd}$ concentration in roots and leaves, the bioconcentration factor (BCF) and the translocation factor (TF). Cd accumulated principally in roots, increasing with metal concentration in the medium. It seemed to stabilize at the highest $\mathrm{Cd}$ dose $(10 \mathrm{mg} / \mathrm{L})$. The maximum concentration in roots was $1000 \mathrm{x}$ that of the control $(1742.1 \mathrm{mg} \mathrm{Cd} / \mathrm{kg} \mathrm{dw}$; $F=86.83, \mathrm{df}=3, p<0.0001)$. Cd accumulation in leaves also increased with metal concentration in water, although not as much as in roots. The maximum concentration in leaves was $100 \times$ that of the control $(147.1 \mathrm{mg} \mathrm{Cd} / \mathrm{kg} \mathrm{dw} ; F=108.09$, $d f=3, p<0.0001)$. BCF were higher in treatments than in control (max. 1233.9; $F=557.35, d f=3, p<0.0001$ ), while $\mathrm{TF}$ were lower than unity $(\mathrm{TF}<1)(F=101.40, d f=3$, $p<0.0001$ ) (Table 3).

\section{Cadmium uptake rate}

The Cd uptake rate for roots and leaves of the water hyacinth showed different functional relations. The relation between the uptake rate for roots and the metal concentration in water adjusted to a logarithmic function, reaching an uptake rate of $248.7 \mathrm{mg} \mathrm{Cd} / \mathrm{kg} \cdot$ day (Fig. 1) in the concentration range studied. Given that the relation between the variables was logarithmic, the $\mathrm{Cd}$ concentrations in water were scaled using a logarithmic transformation to run the linear regression analysis (functional relation: $p<0.01$; lack of adjustment: $p=0.15$; $R^{2}=0.95$ ). As for leaves, the relation between the uptake rate and the $\mathrm{Cd}$ concentration in water adjusted to a linear function (Fig. 2). The metal concentrations in leaves adjusted to an increasing linear function and reached an uptake rate of $20.8 \mathrm{mg} \mathrm{Cd} / \mathrm{kg}$.day in the range of the assayed concentrations (0-10 mg Cd/L).

\section{Discussion}

Contrary to expected, the growth of the water hyacinth was not severely affected by $\mathrm{Cd}$ exposure in the concentration range studied. Despite the observed toxicity symptoms and the decrease in root biomass, there was no unfavorable impact on the RGR. In fact, there was growth stimulation in one of the treatments $(1 \mathrm{mg} \mathrm{Cd} / \mathrm{L})$. This growth could also be due to the presence of chloride (added as $\mathrm{CdCl}_{2} \cdot 2 \frac{1}{2} \mathrm{H}_{2} \mathrm{O}$ ) and other nutrients present in the polluted water from Riachuelo river.
Table 3 Cd concentration in roots and leaves, bioconcentration factor $(\mathrm{BCF})$ and translocation factor (TF) in E. crassipes after 7 days of metal exposure

\begin{tabular}{lcccl}
\hline Treatments & Cd in roots $(\mathrm{mg} / \mathrm{kg} \mathrm{dw})$ & Cd in leaves $(\mathrm{mg} / \mathrm{kg} \mathrm{dw})$ & BCF & \multicolumn{1}{l}{ TF } \\
\hline Cd0 (control) & $1.77 \pm 0.49 \mathrm{a}$ & $1.48 \pm 0.83 \mathrm{a}$ & $25.2 \pm 7.0 \mathrm{a}$ & $0.826 \pm 0.287 \mathrm{a}$ \\
$\mathrm{Cd} 1$ & $748.4 \pm 136.8 \mathrm{~b}$ & $9.73 \pm 3.02 \mathrm{~b}$ & $1233.9 \pm 333.0 \mathrm{~b}$ & $0.013 \pm 0.003 \mathrm{~b}$ \\
$\mathrm{Cd} 5$ & $1580.2 \pm 358.6 \mathrm{c}$ & $51.1 \pm 29.2 \mathrm{c}$ & $846.3 \pm 149.7 \mathrm{c}$ & $0.033 \pm 0.026 \mathrm{c}$ \\
$\mathrm{Cd} 10$ & $1742.1 \pm 327.7 \mathrm{c}$ & $147.4 \pm 95.5 \mathrm{~d}$ & $774.8 \pm 82.5 \mathrm{c}$ & $0.084 \pm 0.049 \mathrm{~d}$ \\
\hline
\end{tabular}

Values expressed as mean $(n=3) \pm$ std. error. Different letters under the same column indicate significant differences $(p<0.05)$ among treatments

$C d 0$ control (no metal addition), $C d 1$ supplemented with $1 \mathrm{mg} \mathrm{Cd} / \mathrm{L}, C d 5$ supplemented with $5 \mathrm{mg} \mathrm{Cd} / \mathrm{L}, C d 10$ supplemented with $10 \mathrm{mg} \mathrm{Cd} / \mathrm{L}$ 


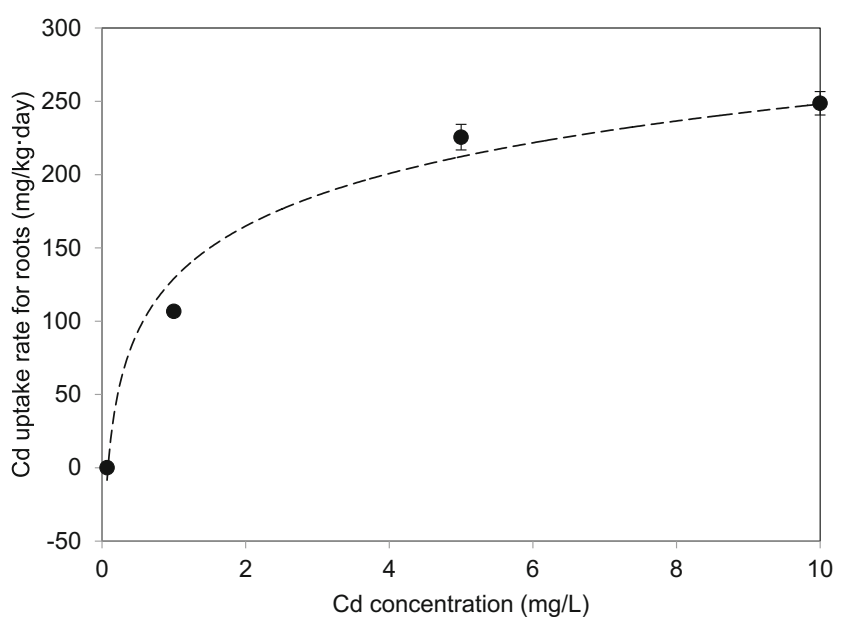

Fig. $1 \mathrm{Cd}$ uptake rate for roots of E. crassipes in function of $\mathrm{Cd}$ treatments after 7 days of metal exposure. References: error bars $=$ standard error (mean of three replicates); dash line $=$ functional relation

These results agree with observations for this species in assays under similar conditions (El-Leboudi et al. 2008; Lu et al. 2004; Hasan et al. 2007) (a summary of the references is presented in Table 4). A few cases registered growth decrease at $1 \mathrm{mg} \mathrm{Cd} / \mathrm{L}$ (Delgado et al. 1993; Smolyakov 2012).

$\mathrm{Cd}$ accumulation in the water hyacinth was considerably high, especially in roots. $\mathrm{Cd}$ concentrations in treated roots in this assay (740-1750 $\mathrm{mg} \mathrm{Cd} / \mathrm{kg} \mathrm{dw}$ ) exceeded several values reported for this species under similar conditions (Mazen and El Maghraby 1997; Soltan and Rashed 2003; El-Leboudi et al. 2008; Aisien et al. 2010). Similar or larger Cd concentrations in roots were also reported (Muramoto and Oki 1983; Kay et al. 1984; Lu et al. 2004; Hasan et al. 2007). The bioconcentration factors obtained in this experiment (774.81233.9) are higher (Lu et al. 2004; Eid et al. 2019) or in the order (Hasan et al. 2007; Aisien et al. 2010) of the ones reported in bibliography.

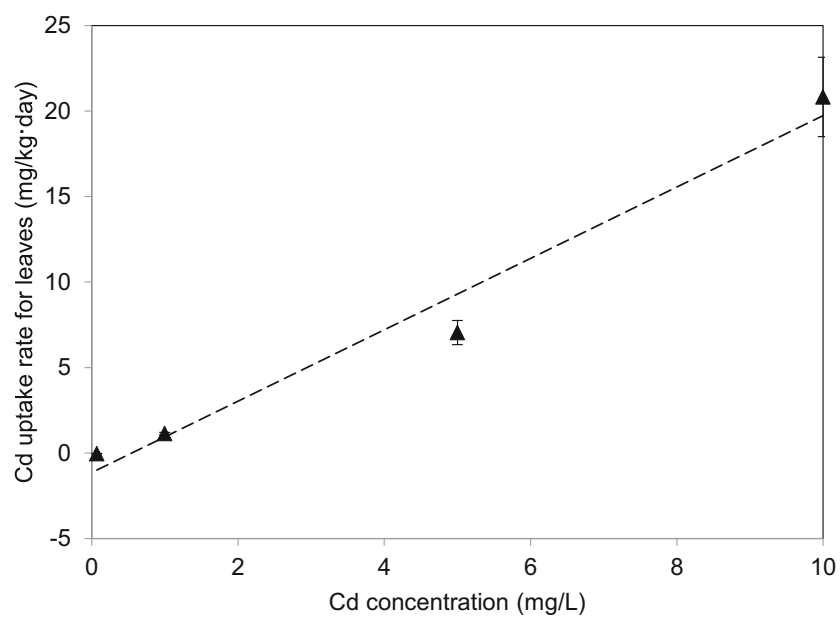

Fig. $2 \mathrm{Cd}$ uptake rate for leaves of E. crassipes in function of $\mathrm{Cd}$ treatments after 7 days of metal exposure. References: error bars $=$ standard error (mean of three replicates); dash line $=$ functional relation
$\mathrm{Cd}$ accumulation in leaves was not as high as in roots, although it showed considerable levels $(9.5-150 \mathrm{mg} \mathrm{Cd} / \mathrm{kg}$ $\mathrm{dw}$ ). Many reports indicate higher values of $\mathrm{Cd}$ accumulation in E. crassipes leaves (Muramoto and Oki 1983; Mazen and El Maghraby 1997; Soltan and Rashed 2003; Hasan et al. 2007). Some authors reported similar values for this species (Soltan and Rashed 2003; Lu et al. 2004; Hasan et al. 2007; Aisien et al. 2010). It is possible that the water hyacinth was not able to translocate large amounts of toxic metals to the leaves as an exclusion strategy for the protection of the photosynthetic apparatus (Benavides et al. 2005; Kirkham 2006; Gallego et al. 2012; Tran and Popova 2013). Consistently with $\mathrm{Cd}$ accumulation in leaves, the translocation factor was low in all treatments (less than one), meaning that $\mathrm{Cd}$ remained mostly in roots. This result is consistent with the reported in bibliography for Cd in water hyacinth (Kamari et al. 2017; Eid et al. 2019).

The pattern of $\mathrm{Cd}$ uptake rate for roots obtained in this experiment was different from that of leaves. The uptake rate for roots seemed to reach its maximum capacity when $\mathrm{Cd}$ concentration in the medium was $5 \mathrm{mg} \mathrm{Cd} / \mathrm{L}$, suggesting that $\mathrm{Cd}$ uptake for $E$. crassipes roots saturates at this level of $\mathrm{Cd}$ in the medium, under the conditions of this experiment. On the other hand, the uptake rate for leaves showed an increasing trend, indicating that $\mathrm{Cd}$ concentrations in leaves do not saturate in the concentration range studied and the uptake rate for leaves has not reached its threshold, under the conditions of this experiment. Wolverton and McDonald (1978) reported a similar uptake rate for roots of E. crassipes after $24 \mathrm{~h}$ of $\mathrm{Cd}$ exposure $(281 \mathrm{mg} \mathrm{Cd} / \mathrm{kg}$ ) and a lower uptake rate for leaves (6.1 $\mathrm{mg} \mathrm{Cd} / \mathrm{kg}$ ) at $0.1 \mathrm{mg} \mathrm{Cd} / \mathrm{L}$.

The toxicity effects observed in this experiment (symptoms of chlorosis, dehydration, and brown color in leaves and petioles) are among the frequent toxicity symptoms in plants due to $\mathrm{Cd}$ exposure. They include inhibition and abnormalities in general growth, reduction of elongation of shoots and roots, leaf curling, and chlorosis (Tran and Popova 2013). Consistently with the results of this experiment, other authors reported symptoms of chlorosis after 2-4 days (Soltan and Rashed 2003; Hasan et al. 2007) under similar Cd concentrations. Damage in leaves and petioles was also observed (O'Keeffe et al. 1984), as well as necrosis (Delgado et al. 1993) and red-brown patches on leaves and stunted stems (Davis et al. 1978).

Some authors reported reaching the threshold of symptom toxicity for $E$. crassipes in the culture medium at $1 \mathrm{mg} \mathrm{Cd} / \mathrm{L}$ (Hasan et al. 2007). White and Brown (2010) informed an accumulation of $5-10 \mathrm{mg} \mathrm{Cd} / \mathrm{kg} \mathrm{dw}$ as the critical leaf concentration of $\mathrm{Cd}$ in crop plants, that is, above which yield decreases $10 \%$. Although the phytotoxic signs were visible in all treatments, the $\mathrm{Cd}$ concentrations bioaccumulated during this experiment, both in roots and leaves, exceeded these limits (9-1750 mg Cd/kg dw). 


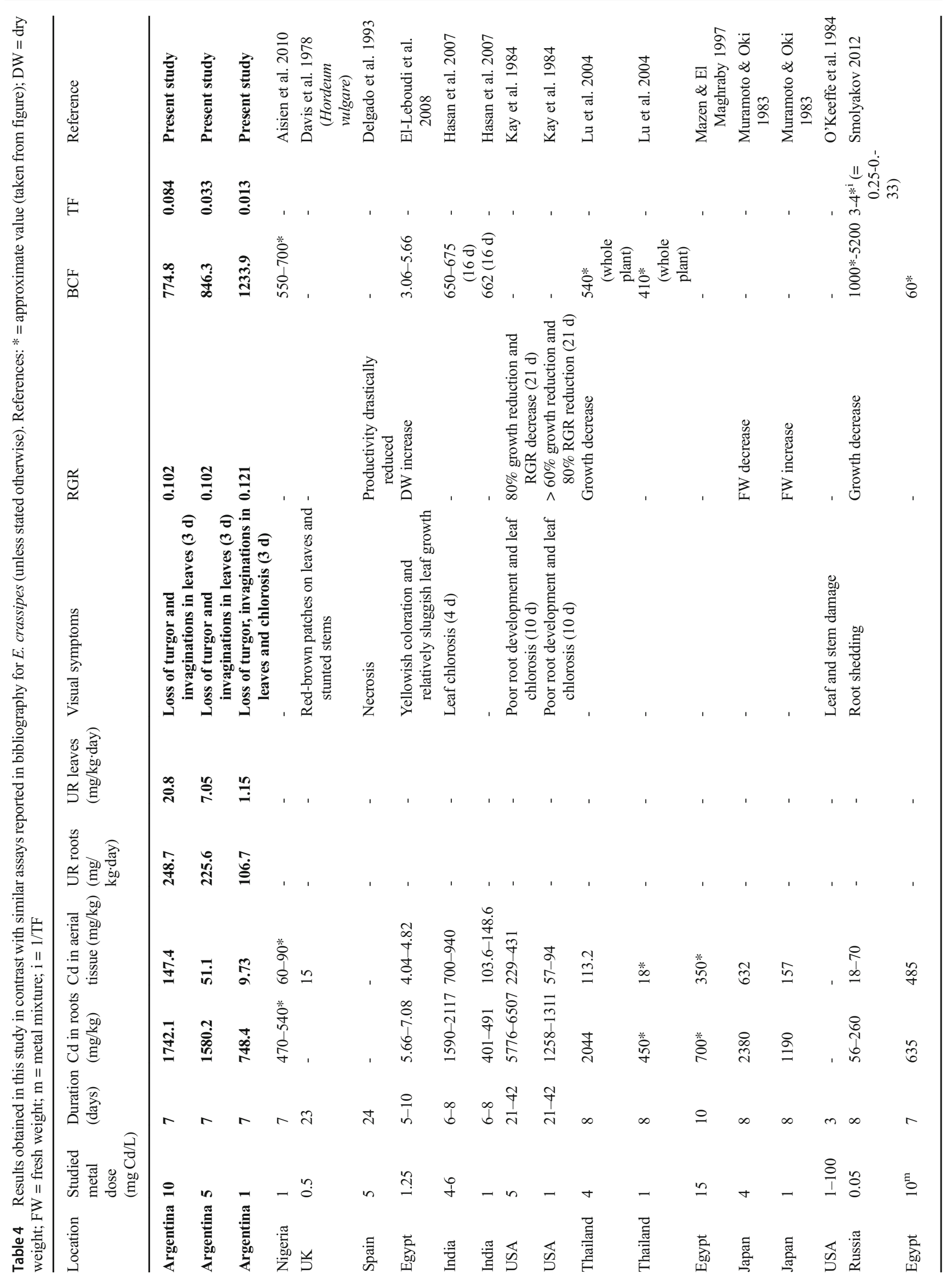




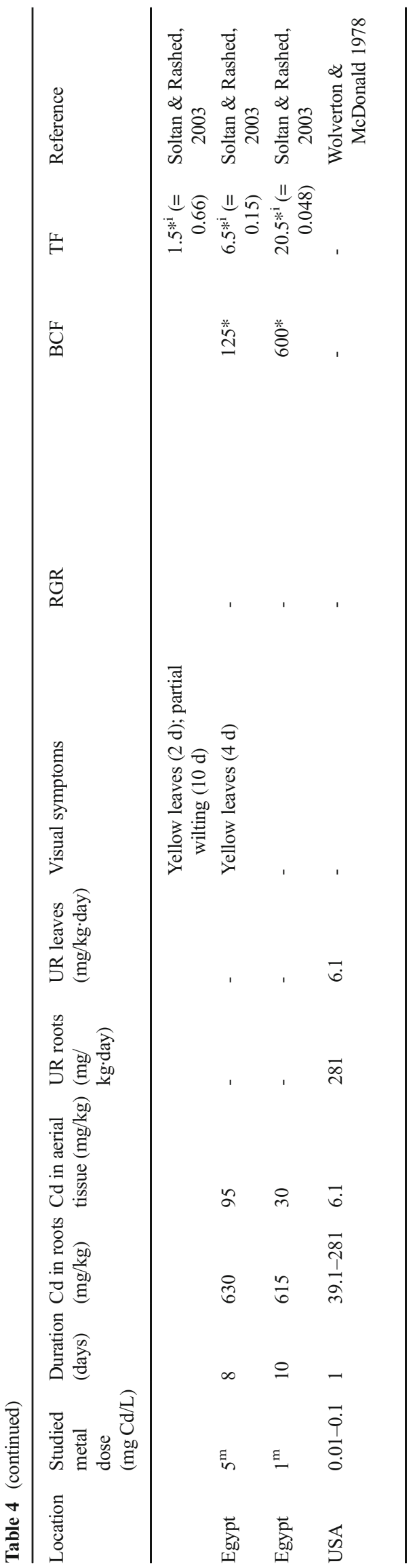

\section{Conclusions}

The water hyacinth $E$. crassipes showed interesting results regarding its capacity to accumulate and tolerate $\mathrm{Cd}$, a nonessential element, in tissues beyond the toxicity limit estimated for this element, without major impact on growth parameters. The results suggest that the water hyacinth is able to tolerate the metal in its roots, while it excludes $\mathrm{Cd}$ from the leaves. Thus, E. crassipes showed a very satisfactory performance regarding $\mathrm{Cd}$ incorporation from polluted stream water supplemented with $\mathrm{Cd}$ in doses above the threshold toxicity for plants in the culture medium. Several rivers in the Pampean region (Castañé et al. 1998; Magdaleno et al. 2001; Magdaleno et al. 2014) receive industrial effluents containing $\mathrm{Cd}$ concentrations above the legal discharge limits $(0.1 \mathrm{mg} / \mathrm{L})$ (ACUMAR 2017). Therefore, these are promising results for the application of the water hyacinth in treatments of industrial effluents and leaching of open air dump where batteries and electronic devices are discarded.

Acknowledgments The authors would like to thank Cristian Weigandt for the determinations of heavy metals and Carlos Hernández for the assistance in the greenhouse.

Funding This study was funded by the Agencia Nacional de Promoción Científica y Tecnológica, Argentina (PICT 00-356) and Consejo Nacional de Investigaciones Científicas y Técnicas, Argentina (PIP 0323).

\section{Compliance with ethical standards}

Conflict of interest The authors declare that they have no conflict of interests.

\section{References}

Abhilash PC, Pandey VC, Srivastava P, Rakesh PS, Chandran S, Singh N, Thomas AP (2009) Phytofiltration of cadmium from water by Limnocharis flava (L.) Buchenau grown in free-floating culture system. J Hazard Mater 170:791-797. https://doi.org/10.1016/j. jhazmat.2009.05.035

ACUMAR (2017) Resolution No. 46/2017. Annex I. Consolidated table of permissible limits for discharge of liquid effluents. Official Bulletin No. 33593, Buenos Aires, Argentina

Aisien FA, Faleye O, Aisien ET (2010) Phytoremediation of heavy metals in aqueous solutions. Leonardo J Sci:37-46

Ali H, Khan E, Sajad MA (2013) Phytoremediation of heavy metalsconcepts and applications. Chemosphere 91:869-881. https://doi. org/10.1016/j.chemosphere.2013.01.075

ANZECC, ARMCANZ (2000) Australian and New Zealand Guidelines for Fresh and Marine Water Quality. National Water Quality Management Strategy Paper No. 4. Australian and New Zealand Environment and Conservation Council \& Agriculture and Resource Management Council of Australia and New Zealand, Canberra

APHA (1999) Standard Methods for the Examination of Water and Wastewater, 20th edn. American Public Health Association, Washington, USA

Argentina (1991) National Law No. 24051 on Hazardous Waste. Official Bulletin No. 27307, Buenos Aires, Argentina 
Basílico G, de Cabo L, Faggi A, Miguel S (2016) Low-tech alternatives for the rehabilitation of aquatic and riparian environments. In: Ansari AA, Singh Gill S, Gill R, Lanza GR, Newman L (eds) Phytoremediation: management of environmental contaminants. Springer International Publishing, Switzerland, pp 349-364

Benavides MP, Gallego SM, Tomaro ML (2005) Cadmium toxicity in plants. Braz J Plant Physiol 17:21-34. https://doi.org/10.1590/ S1677-04202005000100003

Bernhardt A, Gysi N (2013) The worlds worst 2013: the top ten toxic threats. Zurich, Switzerland

Castañé PM, Loez CR, Olguín HF, Puig A, Rovedatti MG, Topalián ML, Salibián A (1998) Caracterización y variación espacial de parámetros fisicoquímicos y del plancton en un río urbano contaminado (río Reconquista, Argentina). Rev Int Contam Ambient 14:69-77

CCME (2014) Canadian Water Quality Guidelines for the Protection of Aquatic Life: Cadmium. Canadian Council of Ministers of the Environment, Winnipeg

Davis RD, Beckett PHT, Wollan E (1978) Critical levels of twenty potentially toxic elements in young spring barley. Plant Soil 49:395408. https://doi.org/10.1007/BF02149747

Delgado M, Bigeriego M, Guardiola E (1993) Uptake of Zn, Cr and Cd by water hyacinths. Water Res 27:269-272. https://doi.org/10.1016/ 0043-1354(93)90085-V

Dhir B, Srivastava S (2011) Heavy metal removal from a multi-metal solution and wastewater by Salvinia natans. Ecol Eng 37:893-896. https://doi.org/10.1016/j.ecoleng.2011.01.007

Dixit R, Wasiullah MD, Pandiyan K, Singh UB, Sahu A, Shukla R, Singh BP, Rai JP, Sharma PK, Lade H, Paul D (2015) Bioremediation of heavy metals from soil and aquatic environment: an overview of principles and criteria of fundamental processes. Sustainability 7 : 2189-2212. https://doi.org/10.3390/su7022189

DWAF (1996) South African Water Quality Guidelines. Volume 7: Aquatic Ecosystems. Department of Water Affairs and Forestry, Pretoria, South Africa

ECYT-AR (2011) Cuenca Matanza-Riachuelo. In: La Encicl. Ciencias y Tecnol. en Argentina. https://cyt-ar.com.ar/cyt-ar/index.php/ Cuenca_Matanza_-_Riachuelo. Accessed 15 Nov 2017

Eid EM, Shaltout KH, Moghanm FS, Youssef MSG, El-Mohsnawy E, Haroun SA (2019) Bioaccumulation and translocation of nine heavy metals by Eichhornia crassipes in Nile Delta, Egypt: perspectives for phytoremediation. Int J Phytoremediation 0:1-10. https://doi.org/10. 1080/15226514.2019.1566885

El-Leboudi AE, Abd-Elmoniem EM, Soliman EM, El-Sayed OFM (2008) Removal of some heavy metals from treated waste water by aquatic plants. In: 3 rd international conference on water resources and arid environments and the 1st Arab Water Forum, Riyadh, Saudi Arabia

Gallego SM, Pena LB, Barcia RA, Azpilicueta CE, Iannone MF, Rosales EP, Zawoznik MS, Groppa MD, Benavides MP (2012) Unravelling cadmium toxicity and tolerance in plants: insight into regulatory mechanisms. Environ Exp Bot 83:33-46. https://doi.org/10.1016/j. envexpbot.2012.04.006

Gómez N (1998) Use of epipelic diatoms for evaluation of water quality in the Matanza-Riachuelo (Argentina), a Pampean plain river. Water Res 32:2029-2034. https://doi.org/10.1016/S0043-1354(97)00448-X

Hasan SH, Talat M, Rai S (2007) Sorption of cadmium and zinc from aqueous solutions by water hyacinth (Eichchornia crassipes). Bioresour Technol 98:918-928. https://doi.org/10.1016/j.biortech. 2006.02.042

Kamari A, Yusof N, Abdullah H, Haraguchi A, Abas MF (2017) Assessment of heavy metals in water, sediment, Anabas testudineus and Eichhornia crassipes in a former mining pond in Perak, Malaysia. Chem Ecol 33:637-651. https://doi.org/10.1080/ 02757540.2017 .1351553
Kay SH, Haller WT, Garrard LA (1984) Effects of heavy metals on water hyacinths (Eichhornia crassipes (Mart.) Solms). Aquat Toxicol 5: 117-128. https://doi.org/10.1016/0166-445X(84)90003-1

Khellaf N, Zerdaoui M (2010) Growth response of the duckweed Lemna gibba L. to copper and nickel phytoaccumulation. Ecotoxicology 19:1363-1368. https://doi.org/10.1007/s10646-010-0522-z

Kirkham MB (2006) Cadmium in plants on polluted soils: effects of soil factors, hyperaccumulation, and amendments. Geoderma 137:1932. https://doi.org/10.1016/j.geoderma.2006.08.024

Körner S, Das SK, Veenstra S, Vermaat JE (2001) The effect of pH variation at the ammonium/ammonia equilibrium in wastewater and its toxicity to Lemna gibba. Aquat Bot 71:71-78. https://doi. org/10.1016/S0304-3770(01)00158-9

Lu X, Kruatrachue M, Pokethitiyook P, Homyok K (2004) Removal of cadmium and zinc by water hyacinth, Eichhornia crassipes. Sci Asia 30:93-103

Lux A, Martinka M, Vaculík M, White PJ (2011) Root responses to cadmium in the rhizosphere: a review. J Exp Bot 62:21-37. https:// doi.org/10.1093/jxb/erq281

Magdaleno A, Puig A, De Cabo L, Salinas C, Arreghini S, Korol S, Bevilacqua S, López L, Moretton J (2001) Water pollution in an urban Argentine river. Bull Environ Contam Toxicol 67:408-415

Magdaleno A, De Cabo L, Arreghini S, Salinas S (2014) Assessment of heavy metal contamination and water quality in an urban river from Argentina. Braz J Aquat Sci Technol 18:113. https://doi.org/10. 14210/bjast.v18n1.p113-120

Malar S, Vikram SS, Favas PJ, Perumal V (2014) Lead heavy metal toxicity induced changes on growth and antioxidative enzymes level in water hyacinths [Eichhornia crassipes (Mart.)]. Bot Stud 55:54. https://doi.org/10.1186/s40529-014-0054-6

Malar S, Sahi SV, Favas PJC, Venkatachalam P (2015) Mercury heavymetal-induced physiochemical changes and genotoxic alterations in water hyacinths [Eichhornia crassipes (Mart.)]. Environ Sci Pollut Res 22:4597-4608. https://doi.org/10.1007/s11356-014-3576-2

Mazen AMA, El Maghraby OMO (1997) Accumulation of cadmium, lead and strontium, and a role of calcium oxalate in water hyacinth tolerance. Biol Plant 40:411-417. https://doi.org/10.1023/A: 1001174132428

Melignani E, de Cabo LI, Faggi AM (2015) Copper uptake by Eichhornia crassipes exposed at high level concentrations. Environ Sci Pollut Res Int 22:8307-8315. https://doi.org/10.1007/s11356-014-3972-7

Mishra VK, Tripathi BD (2008) Concurrent removal and accumulation of heavy metals by the three aquatic macrophytes. Bioresour Technol 99:7091-7097. https://doi.org/10.1016/j.biortech.2008.01.002

Muramoto S, Oki Y (1983) Removal of some heavy metals from polluted water by water hyacinth (Eichhornia crassipes). Bull Environ Contam Toxicol 30:170-177. https://doi.org/10.1007/BF01610117

Nagajyoti PC, Lee KD, Sreekanth TVM (2010) Heavy metals, occurrence and toxicity for plants: a review. Environ Chem Lett 8:199216. https://doi.org/10.1007/s10311-010-0297-8

O'Keeffe DH, Hardy JK, Rao RA (1984) Cadmium uptake by the water hyacinth: effects of solution factors. Environ Pollut Ser A Ecol Biol 34:133-147. https://doi.org/10.1016/0143-1471(84)90054-0

Park S, Kang D, Kim Y, Lee SM, Chung Y, Sung K (2011) Biosorption and growth inhibition of wetland plants in water contaminated with a mixture of arsenic and heavy metals. Eng Life Sci 11:84-93. https://doi.org/10.1002/elsc.201000024

Phetsombat S, Kruatrachue M, Pokethitiyook P, Upatham S (2006) Toxicity and bioaccumulation of cadmium and lead in Salvinia cucullata. J Environ Biol 27:645-652

Rezania S, Ponraj M, Talaiekhozani A, Mohamad SE, Fadhil M, Din M, Taib SM, Sabbagh F, Sairan FM (2015) Perspectives of phytoremediation using water hyacinth for removal of heavy metals, organic and inorganic pollutants in wastewater. J Environ Manag 163:125-133. https://doi.org/10.1016/j.jenvman.2015.08.018 
Rezania S, Taib SM, Din MFM, Dahalan FA, Kamyab H (2016) Comprehensive review on phytotechnology: heavy metals removal by diverse aquatic plants species from wastewater. J Hazard Mater 318:587-599. https://doi.org/10.1016/j.jhazmat.2016.07.053

Rodríguez-Serrano M, Martínez-de la Casa N, Romero-Puertas MC, del Río LA, Sandalio LM (2008) Toxicidad del cadmio en plantas. Rev Ecosistemas 17:139-146 in Spanish

Sanità di Toppi L, Gabbrielli R (1999) Response to cadmium in higher plants. Environ Exp Bot 41:105-130. https://doi.org/10.1016/ S0098-8472(98)00058-6

Singh RP, Agrawal M (2007) Effects of sewage sludge amendment on heavy metal accumulation and consequent responses of Beta vulgaris plants. Chemosphere 67:2229-2240. https://doi.org/10. 1016/j.chemosphere.2006.12.019

Smolyakov BS (2012) Uptake of $\mathrm{Zn}, \mathrm{Cu}, \mathrm{Pb}$, and $\mathrm{Cd}$ by water hyacinth in the initial stage of water system remediation. Appl Geochem 27: 1214-1219. https://doi.org/10.1016/j.apgeochem.2012.02.027

Soltan ME, Rashed MN (2003) Laboratory study on the survival of water hyacinth under several conditions of heavy metal concentrations. Adv Environ Res 7:321-334. https://doi.org/10.1016/S10930191(02)00002-3

Sood A, Uniyal PL, Prasanna R, Ahluwalia AS (2012) Phytoremediation potential of aquatic macrophyte, Azolla. AMBIO A J Hum Environ 41:122-137. https://doi.org/10.1007/s13280-011-0159-Z
Sukumaran D (2013) Phytoremediation of heavy metals from industrial effluent using constructed wetland technology. Appl Ecol Environ Sci 1:92-97. https://doi.org/10.12691/aees-1-5-4

Tran TA, Popova LP (2013) Functions and toxicity of cadmium in plants: recent advances and future prospects. Turk J Botany 37:1-13. https://doi.org/10.3906/bot-1112-16Functions

USEPA (2016) Aquatic life ambient water quality criteria cadmium 2016. United States Environmental Protection Agency

White PJ, Brown PH (2010) Plant nutrition for sustainable development and global health. Ann Bot 105:1073-1080. https://doi.org/10.1093/ aob/mcq085

Wolverton BC, McDonald RC (1978) Bioaccumulation and detection of trace levels of cadmium in aquatic systems by Eichhornia crassipes. Environ Health Perspect 27:161-164. https://doi.org/10.2307/ 3428875

Publisher's note Springer Nature remains neutral with regard to jurisdictional claims in published maps and institutional affiliations. 